\title{
STUDIES IN IMPERIALISM
}

\section{Country houses and the}

British Empire,

1700-1930

STEPHANIE BARCZEWSKI

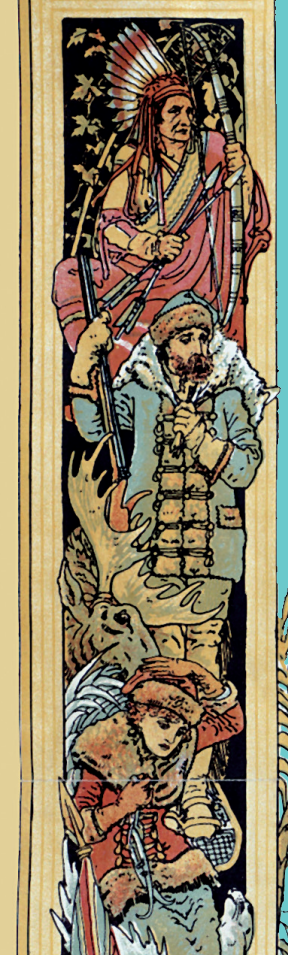




\section{IMPERIES IN-}

general editors John M. MacKenzie and Andrew S. Thompson

When the 'Studies in Imperialism' series was founded more than twenty-five years ago, emphasis was laid upon the conviction that 'imperialism as a cultural phenomenon had as significant an effect on the dominant as on the subordinate societies'. With well over a hundred titles now published, this remains the prime concern of the series. Cross-disciplinary work has indeed appeared covering the full spectrum of cultural phenomena, as well as examining aspects of gender and sex, frontiers and law, science and the environment, language and literature, migration and patriotic societies, and much else. Moreover, the series has always wished to present comparative work on European and American imperialism, and particularly welcomes the submission of books in these areas. The fascination with imperialism, in all its aspects, shows no sign of abating, and this series will continue to lead the way in encouraging the widest possible range of studies in the field. 'Studies in Imperialism' is fully organic in its development, always seeking to be at the cutting edge, responding to the latest interests of scholars and the needs of this ever-expanding area of scholarship.

\section{Country houses and the British Empire, 1700-1930}

\section{MANCHESTER 1824}

Manchester University Press 


\title{
SELECTED TITLES AVAILABLE IN THE SERIES
}

\author{
REPRESENTING AFRICA
}

Landscape, exploration and empire in Southern Africa, 1780-1870

John McAleer

VISIONS OF EMPIRE

Patriotism, popular culture and the city, 1870-1939

Brad Beaven

EMPIRE OF SCHOLARS

Universities, networks and the British academic world, 1850-1939

Tamson Pietsch

CURATING EMPIRE

Museums and the British imperial experience

Edited by Sarah Longair and John McAleer

MUSEUMS AND EMPIRE

Natural history, human cultures and colonial identities

John M. MacKenzie 


\title{
Country houses and the British \\ Empire, 1700-1930
}

Stephanie Barczewski

\author{
MANCHESTER \\ UNIVERSITY PRESS \\ Manchester and New York \\ distributed in the United States exclusively by \\ PALGRAVE MACMILLAN
}


Copyright (C) Stephanie Barczewski 2014

The right of Stephanie Barczewski to be identified as the author of this work has been asserted by him/her in accordance with the Copyright, Designs and Patents Act 1988.

Published by MANCHESTER UNIVERSITY PRESS

ALTRINCHAM STREET, MANCHESTER M1 7JA, UK

and ROOM 400, 175 FIFTH AVENUE, NEW YORK, NY 10010, USA

www.manchesteruniversitypress.co.uk

Distributed in the United States exclusively by

PALGRAVE MACMILLAN, 175 FIFTH AVENUE, NEW YORK, NY 10010, USA

Distributed in Canada exclusively by

UBC PRESS, UNIVERSITY OF BRITISH COLUMBIA,

2029 WEST MALL, VANCOUVER, BC, CANADA V6T $1 Z 2$

British Library Cataloguing-in-Publication Data

A catalogue record for this book is available from the British Library

Library of Congress Cataloging-in-Publication Data applied for

ISBN 9780719096228 hardback

First published 2014

The publisher has no responsibility for the persistence or accuracy of URLs for any external or third-party internet websites referred to in this book, and does not guarantee that any content on such websites is, or will remain, accurate or appropriate.

Typeset in 10/12pt Trump Mediaeval

by Graphicraft Limited, Hong Kong 